\title{
Physics Online Learning Devices Based on Guided Discovery Model for High School Class X on Momentum and Impulse Material
}

\author{
Eko Mhd Ramadan ${ }^{1, a)}$, Jumadi ${ }^{2}$, Dwi Ulan Rahmawati ${ }^{1}$ \\ ${ }^{1}$ Physics Education Study Program, Postgraduate, Yogyakarta State University \\ Jl. Colombo No. 1, Karang Malang, Caturtunggal, Kec. Depok, Sleman Regency, Special Region of \\ Yogyakarta 55281 Indonesia \\ ${ }^{2}$ Natural Sciences Education Study Program, Postgraduate, Yogyakarta State University \\ Jl. Colombo No. 1, Karang Malang, Caturtunggal, Kec Depok, Sleman Regency, Special Region of \\ Yogyakarta 55281 Indonesia \\ a)ekomhd.2018@student.uny.ac.id
}

\begin{abstract}
This development research aims to develop online physics learning tools based on guided discovery models for high school grade $\mathrm{X}$ students with momentum and impulse material and test the feasibility of Physics online learning tools through validator assessments (material experts, material experts) and limited trials by students' responses. Physics online learning tools developed in the syllabus, lesson plans, student worksheets, handouts, and learning media. The average score of validation assessment for the syllabus is 4.81 , the lesson plan is 4.72 , the student worksheet is 4.64 , the handout is 4.57 , the media is 4.76 , and the media material is 4.66 . All in categorized as very worthy. In this study, a limited trial was conducted for 27 students divided into three groups. The average score results student on worksheet one is 4.06 , worksheet two is 3.98, and worksheet three is 3.87. All in with categories worthy. The average score result of handout one is 4.04 , handout two is 3.96 , and handout three is 4.01 . All in with worthy category. The results obtained from the Physics online learning tool based on guided discovery models are appropriate for online learning on momentum and impulse material for grade $\mathrm{X}$ high school students.
\end{abstract}

Keywords: online learning tools, guided discovery, momentum dan impulse

\section{INTRODUCTION}

The expansion of technology in this era called the 4.0 Revolution-era provides many changes in every aspect of life, including improving the quality of education (Qomariyah, Gunarhadi, and Rejekiningsih 2018). Technology is a facility for students and teachers to have classes without face-toface meetings and online courses using all kinds of products from technology (Rahmi et al. 2018; Trinder 2015). At present, computers and the internet are done easily and quickly to convey learning material information via email, websites, and online learning systems (Qomariyah et al. 2018; Rahmi et al. 2018). In 2018, more than 7 million high school and high school students out of a total of all 14.9 million middle and high school students in Indonesia have studied online with various applications (Kemendikbud 2018; Usman 2018). Although wireless and cellular technology are considered useful tools for enhancing learner-centered learning, the lack of online-based learning tools has resulted in teachers' instructional beliefs and practices not being willing to use online-based learning (Liu 2007). 
The learning process of 21st-century competence in using the internet requires students to be directly involved, not just limited to searching for information, but students can carry out learning online (Wijayanti, Maharta, and Suana 2017). Many educators are still not utilizing internet facilities. This is contrary to the demands of 21st-century competence. Based on this, educators must be able to develop learning tools that can facilitate online learning.

Today, computers are an essential part of daily life for students. Teaching and learning methods must inevitably include e-learning components and be based on computers (Martin and Madigan 2006). This pedagogy can study high-level thinking skills, and constructivism approaches the pursuit and learning of science, information, communication, and scientific literacy skills using digital and technological means (Cavus and Alhih 2014).

The development of Physics online learning tools applies to the 2013 Curriculum. The suggested learning models in the 2013 curriculum are guided models (Putri and Jumadi 2017). Learning tools are something that educators must prepare before implementing learning (Suprahatiningrum 2013).

The development of learning tools by applying guided discovery learning models is efficient and effective when used in the learning process (Habibbulloh, Jatmiko, and Widodo 2017). Analysis of Yusnia \& Suparman (2018) teaching materials based on guided discovery models can help students understand the material, be active in the learning process, and create interesting learning.

Learning tools arrange following the Ministry of Education and Culture (2016), consisting of the syllabus, Learning Implementation Plan (RPP), media, and teaching materials. This research develops online learning tools in the syllabus, lesson plans, handouts, and learning media. Student Worksheets (LKPD) follow the guidelines for the development of MONE teaching materials (2008).

The online learning system is a new system in education that utilizes information technology to support the learning process (Susilo and Rohman 2019). Online learning is indeed very relevant for today's millennial generation, especially in certain conditions where it is impossible to carry out learning face to face in the classroom.

The teacher can implement online learning using a Learning Management System (LMS) (Wijayanti et al. 2017) or a Content Management System (CMS). One of the well-known CMS is WordPress. WordPress has several advantages, including free, open source-based, easy to operate, lots of plugins that are always developing, SEO friendly, and can be used offline (Bakri, Sunaryo, Irawan, \& Muliyati 2018). Even so, for online learning, it is more comfortable to use an LMS (Akrivi, Troussas, \&Virvou 2017). LMS Schoology is a website that combines e-learning and social networking. LMS Schoology has the same concept as other LMS, but in e-learning, Schoology has many advantages such as courses, group discussions, resources, quiz attendance, and analytics (Aminoto and Patoni 2015).

Momentum and impulse are the topics chosen in this study. Momentum is a vector quantity. People can measure a particle's momentum as the difficulty of settling a particle (Rezeki \& Ishafit 2017). This topic is due to several reasons, including momentum and impulse material, which have many applications in everyday life, and now students still consider it difficult (Malik, Vitriani, and Chusni 2018). However, many students still have difficulty interpreting the concepts of momentum and impulse (Malik, Vitriani, and Chusni 2018). Also, momentum and impulses are subtopics of mechanics and basic concepts in physics (Denny, Utami, Rohanah, and Mulyati 2020). Based on previous research results, we will develop an Online Physics Learning Tool Based on the Guided Discovery Model for Senior High Schools in Class X on Momentum and Impulse Materials.

\section{RESEARCH METHOD}

This type of research is research and development (R\&D) research. Research and Development ( $R$ $\&$ D) research methods are research methods used to produce a product by testing the effectiveness of the product (Sugiyono 2015). The development and research were carried out using the 4D approach. The 4D model consists of four stages: defining, designing, developing, and assessing (Thiagarajan, Semmel, and Semeel 1974).

Researchers conducted the research starting from January 1 2020, carried out at SMAN 1 Ngemplak, Sleman. The research subjects were material experts, media experts, physics teachers, and peers as validators and students of class X MIPA of SMA Negeri 1 Ngemplak as subjects of field trials. 
Data collection methods in this study used a questionnaire. The questionnaire is a list of questions related to the product developed that must be filled in by respondents (Arikunto 2013). The questionnaire was used to measure the feasibility of Physics online learning devices using a Likert scale. The Likert scale in this research questionnaire consisted of 5 categories, according to the rubric.

The data obtained is converted into qualitative values based on ideal research criteria. The provisions of the ideal evaluation criteria are shown in TABLE 1.

TABLE 1. Ideal Assessment Criteria (Widiyoko, 2011)

\begin{tabular}{lc}
\multicolumn{1}{c}{ Score Range } & Category \\
\hline $\mathrm{Xi}+1.80 \mathrm{Sbi}<\mathrm{X}$ & Very worthy \\
$\mathrm{Xi}+0.60 \mathrm{Sbi}<\mathrm{X} \leq \mathrm{Xi}+1.80 \mathrm{Sbi}$ & Worthy \\
$\mathrm{Xi}-0.60 \mathrm{Sbi}<\mathrm{X} \leq \mathrm{Xi}+0.60 \mathrm{Sbi}$ & Worthy enough \\
$\mathrm{Xi}-1.80 \mathrm{Sbi}<\mathrm{X} \leq \mathrm{Xi}-0.60 \mathrm{Sbi}$ & Unworthy \\
$\mathrm{X} \leq \mathrm{Xi}-1.80 \mathrm{Sbi}$ & Very unworthy \\
\hline
\end{tabular}

Information:

$\mathrm{X}=$ score achieved

$\mathrm{Xi}=$ Mean ideal

$=1 / 2($ maximum score - minimum score $)$

Sbi $=$ Standard deviation is ideal

$=(1 / 6)($ maximum score - minimum score $)$

\section{RESULTS AND DISCUSSION}

Results of the assessment of the feasibility of online learning tools by experts consisting of the feasibility of the syllabus, RPP, LKPD, handouts, media, and media materials as well as the results of the discussion of the feasibility of limited testing include the feasibility of student worksheet 1 , student worksheet 2 , student worksheet 3 , handout 1 , handout 2 , and handout 3 .

The result of student worksheet 1 , student worksheet 2 , student worksheet 3 , handout 1 , handout 2 , and handout 3 shown in Figure 1-6. Experts carried out the assessment by two lecturers, two physics teachers, and three colleagues. As a result of the eligibility by experts shown in Table 2-7.

TABLE 2. Results of the Syllabus Feasibility Assessment

\begin{tabular}{lcc}
\hline \multicolumn{1}{c}{ Assessment aspects } & Average Results of Rating & Category \\
\hline Completeness of components and & 5 & Very worthy \\
syllabus identity & & \\
Formulation of indicators & 4.85 & Very worthy \\
Learning Activities & 4.85 & Very worthy \\
Learning materials & 4.85 & Very worthy \\
Learning Assessment & 4.71 & Very worthy \\
Time & 4.71 & Very worthy \\
Language & 4.71 & Very worthy \\
\hline Average & $\mathbf{4 . 8 1}$ & Very worthy \\
\hline
\end{tabular}

Based on the results obtained in TABLE 2, overall, it can be concluded that the syllabus, including the category, is very feasible. 
TABLE 3. RPP Feasibility Assessment Results

\begin{tabular}{lcc}
\hline \multicolumn{1}{c}{ Assessment aspects } & Average Results of Rating & Category \\
\hline Subject identity & 4.85 & Very worthy \\
Core Competencies (KI) & 5 & Very worthy \\
Basic Competency (KD) & 4.85 & Very worthy \\
Learning indicator & 4.71 & Very worthy \\
Learning objectives & 4.42 & Very worthy \\
Teaching material & 4.66 & Very worthy \\
Time Allocation & 5 & Very worthy \\
Learning approaches, models and & 4.42 & Very worthy \\
methods & & \\
Learning Activities & 4.89 & Very worthy \\
Assessment & 4.42 & Very worthy \\
Assessment & 4.71 & Very worthy \\
\hline Average & $\mathbf{4 . 7 2}$ & Very worthy \\
\hline
\end{tabular}

Based on TABLE 3, it can be concluded that the RPP developed has very decent criteria.

TABLE 4. Results of the Student Worksheet Feasibility Assessment

\begin{tabular}{lcc}
\hline \multicolumn{1}{c}{ Assessment aspects } & Average Results of Rating & Category \\
\hline Content eligibility & 4.78 & Very worthy \\
Linguistic & 4.60 & Very worthy \\
Serving & 4.62 & Very worthy \\
Grapefruit & 4.56 & Very worthy \\
\hline Average & $\mathbf{4 . 6 4}$ & Very worthy \\
\hline
\end{tabular}

Based on TABLE 4, it can be concluded that the developed LKPD has very decent criteria.

TABLE 5. Results of Handout Feasibility Assessment

\begin{tabular}{lcc}
\hline \multicolumn{1}{c}{ Assessment aspects } & Average Results of Rating & Category \\
\hline Content eligibility & 4.67 & Very worthy \\
Linguistic & 4.64 & Very worthy \\
Serving & 4.42 & Very worthy \\
Grapefruit & 4.56 & Very worthy \\
\hline Average & $\mathbf{4 . 5 7}$ & Very worthy \\
\hline
\end{tabular}

Based on the results of TABLE 5, it can be concluded that the developed handouts have very decent criteria.

TABLE 6. Media Feasibility Assessment Results

\begin{tabular}{lcc}
\hline \multicolumn{1}{c}{ Assessment aspects } & Average Results of Rating & Category \\
\hline System quality & 4.88 & Very worthy \\
Quality of information/content & 4.66 & Very worthy \\
How to deliver the system (system & 4.75 & Very worthy \\
delivers) Form of use & & \\
\hline Average & $\mathbf{4 . 7 6}$ & Very worthy
\end{tabular}

Based on TABLE 6, it can be concluded that the developed media has very decent criteria.

TABLE 7. Media Material Feasibility Assessment Results

\begin{tabular}{lcc}
\hline \multicolumn{1}{c}{ Assessment aspects } & Average Results of Rating & Category \\
\hline Fill in the material & 4.66 & Very worthy \\
Language and writing material & 4.66 & Very worthy \\
\hline Average & $\mathbf{4 . 6 6}$ & Very worthy \\
\hline
\end{tabular}


Based on TABLE 7, it can be concluded that the material in the media that was developed has very decent criteria.

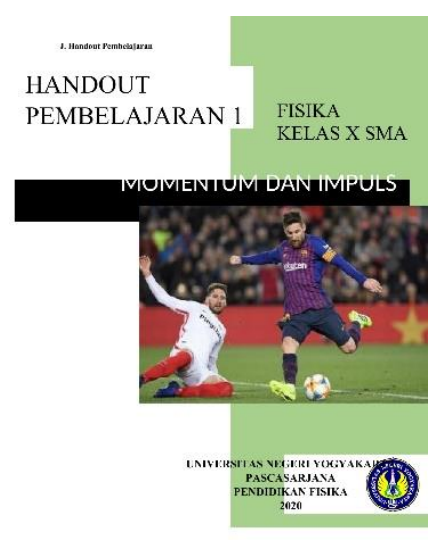

(1)

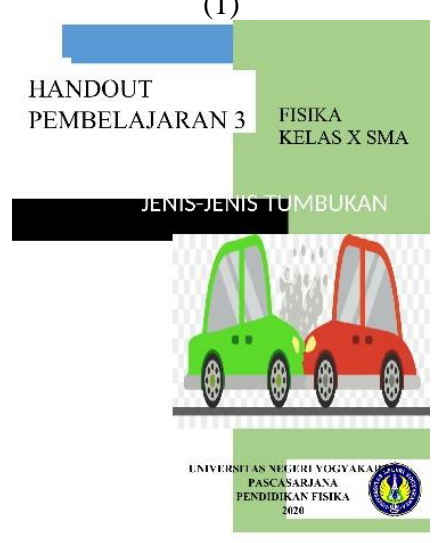

(3)

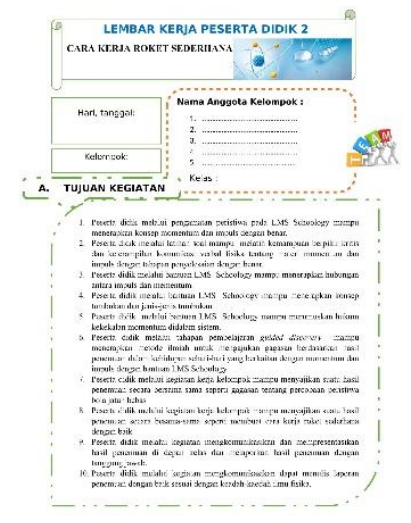

(5)

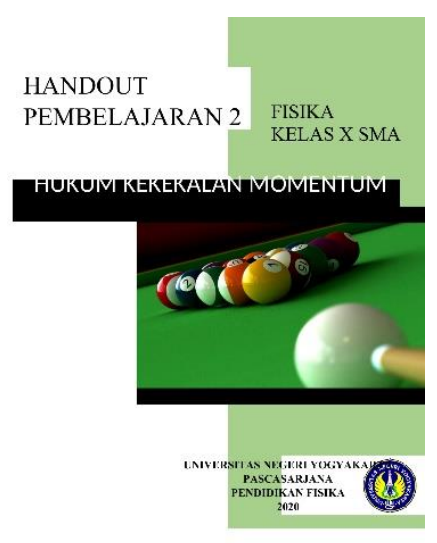

(2)

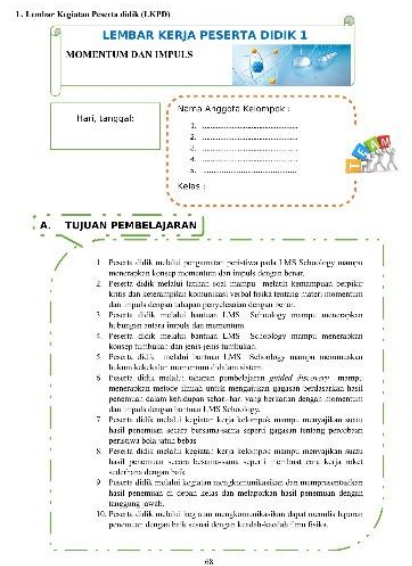

(4)

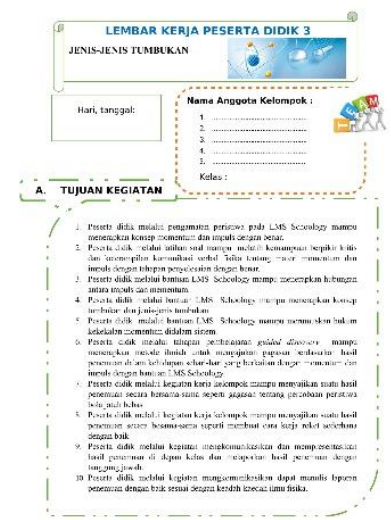

(6)

FIGURE 1. Cover of Handout 1, FIGURE 2. Cover of Handout 2, FIGURE 3. Cover of Handout 3,

FIGURE 4. Cover of Student Worksheet 4, FIGURE 5. Cover of Student Worksheet 5, and

FIGURE 6. Cover of Student Worksheet 6

The results of limited trials were conducted to see the readability of student worksheet, handouts, and material on the media. The results are converted in quantitative descriptive as shown in the Table $8-13$. 


\section{1) The results of the limited trial of student worksheets}

The limited trial was conducted on 27 students and divided into 3 groups of responders, every group is 9 respondents. Each group assesses different student worksheets, namely student worksheet 1 , student worksheet 2 , and student worksheet 3 can be seen in the table.

TABLE 8. Results of Student Respondents Against Student worksheet 1

\begin{tabular}{lcc}
\hline \multicolumn{1}{c}{ Assessment aspects } & Average Results of Rating & Category \\
\hline Content eligibility & 4.02 & Worthy \\
Language & 4.22 & Very worthy \\
Serving & 4.04 & Worthy \\
Graphics & 3.97 & Worthy \\
\hline Average & $\mathbf{4 . 0 6}$ & Worthy \\
\hline
\end{tabular}

Based on TABLE 8, it can be concluded that student worksheet 1 has a decent category.

TABLE 9. Results of Student Respondents Against Student worksheet 2

\begin{tabular}{lcc}
\hline \multicolumn{1}{c}{ Assessment aspects } & Average Results of Rating & Category \\
\hline Content eligibility & 4.11 & Worthy \\
Language & 3.89 & Worthy \\
Serving & 3.96 & Worthy \\
Graphics & 3.97 & Worthy \\
\hline Average & $\mathbf{3 . 9 8}$ & Worthy \\
\hline
\end{tabular}

Based on TABLE 9, it can be concluded that student worksheet 2 has a decent category to use.

TABLE 10. Results of Student Respondents Against Student worksheet 3

\begin{tabular}{lcc}
\hline \multicolumn{1}{c}{ Assessment aspects } & Average Results of Rating & Category \\
\hline Content eligibility & 3.85 & Worthy \\
Language & 3.85 & Worthy \\
Serving & 3.91 & Worthy \\
Graphics & 3.86 & Worthy \\
\hline Average & $\mathbf{3 . 8 7}$ & Worthy \\
\hline
\end{tabular}

Based on TABLE 10, it can be concluded that student worksheet 3 has a decent category to use.

\section{2) The trial results are limited to handouts}

The limited trial was conducted on 27 students and divided into 3 groups of responders, every group is 9 respondents. Each group assesses a different handout, namely handout 1, handout 2 and handout 3 can be seen in the table.

TABLE 11. Results of Student Respondents Against Handout 1

\begin{tabular}{lcc}
\hline \multicolumn{1}{c}{ Assessment aspects } & Average Results of Rating & Category \\
\hline Content eligibility & 4.04 & Worthy \\
Language & 3.86 & Worthy \\
Serving & 4.07 & Worthy \\
Graphics & 4.19 & Worthy \\
\hline Average & $\mathbf{4 . 0 4}$ & Worthy \\
\hline
\end{tabular}

Based on TABLE 11, it can be concluded that Handout 1 is categorized as decent to use.

TABLE 12. Results of Student Respondents Against Handout 2

\begin{tabular}{lcc}
\hline \multicolumn{1}{c}{ Assessment aspects } & Average Results of Rating & Category \\
\hline Content eligibility & 4.13 & Worthy \\
Language & 3.97 & Worthy \\
Serving & 3.96 & Worthy \\
Graphics & 3.78 & Worthy \\
\hline Average & $\mathbf{3 . 9 6}$ & Worthy \\
\hline
\end{tabular}


Based on TABLE 12, it can be concluded that Handout 2 is categorized as decent to use.

TABLE 13. Results of Student Respondents Against Handout 3

\begin{tabular}{lcc}
\hline \multicolumn{1}{c}{ Assessment aspects } & Average Results of Rating & Category \\
\hline Content eligibility & 4.06 & Worthy \\
Language & 4.25 & Very Worthy \\
Serving & 3.89 & Worthy \\
Graphics & 3.85 & Worthy \\
\hline Average & $\mathbf{4 . 0 1}$ & Worthy \\
\hline
\end{tabular}

Based on TABLE 13, it can be concluded that Handout 3 has a decent category to use.

\section{3) Results of limited trials with LMS Schoology media}

The LMS Schoology media trial was conducted on 5 students. The results of the limited trial of the LMS Schoology media can be seen in TABLE 14.

TABLE 14. Results of student respondents to the LMS Schoology media

\begin{tabular}{lcc}
\hline \multicolumn{1}{c}{ Assessment aspects } & Average Results of Rating & Category \\
\hline Content of the material & 3.73 & Worthy \\
Display/operation & 4.27 & Very Worthy \\
\hline Average & $\mathbf{4 . 0 0}$ & Worthy \\
\hline
\end{tabular}

Based on TABLE 14, it can be concluded that the LMS Schoology media has a decent category.

Previous research results, learning using a blended learning model assisted by the Learning Management System (LMS) Edmodo, influenced students' critical thinking skills (Denny, Utami, Rohanah, and Mulyati 2020). Learning on momentum and impulse material can also use the Student Facilitator and Explaining (SFAE) cooperative learning model, which can increase critical thinking skills (Malik, Vitriani, and Chusni 2018). Android-based interactive mobile physics learning on momentum and impulse material can improve higher-order thinking skills (HOTS) and 21st-century skills (Eveline, Suparno, Ardiyanti, Dasilva 2019).

\section{CONCLUSION}

A physics online learning tool based on the guided discovery model has been developed on momentum and impulse for Class X Senior High Schools. There is a syllabus, lesson plans, student worksheets, handouts, and learning media. Based on the results of the experts' feasibility assessment (lecturers, teachers, and peers), the online learning tools developed are in the very feasible category. Based on the limited trial assessment results at SMA Negeri 1 Ngemplak, namely student worksheet, handouts, and LMS Schoology media in the decent category. It can be concluded that physics online learning tools based on the guided discovery learning model can be used in online learning on momentum and impulse material.

\section{ACKNOWLEDGMENTS}

Thank you to the Ministry of Research, Technology and Higher Education, Directorate of Research and Community Service for funding this research.

\section{REFERENCES}

Aminoto, T \& Patoni, P 2015, 'Penerapan Media E-Learning Berbasis Tekhnologi Untuk Meningkatkan Hasil Belajar Materi Usaha Dan Energi Di Kelas IX SMAN 10 Kota Jambi', MATEC Web of Conferences, vol. 28, no. 1, pp. 13-29.

Arikunto, S 2013, ‘Validitas dalam Dasar-Dasar Evaluasi Pendidikan’, Jakarta: Bumi Aksara. 
Bakri, F, Sunaryo, Irawan, VF, \& Muliyati D 2018, 'E-Learning Model for Problem Based Learning onHeatand Thermodynamic Topicsin High School', Jurnal Penelitian dan Pengembangan Pendidikan Fisika (JPPPF), vol. 4, no.2, pp. 101-112.

Cavus, N \& Alhih, MS 2014, 'Learning Management Systems Use in Science Education', Procedia Social and Behavioral Sciences, vol. 143, February 2014, pp. 517-20.

Data Statistik Kemendibud 2018, 'Laporan Jumlah Siswa SMP Dan SMA Di Indonesia Tahun 2018', Jakarta.

Denny, YR, Utami, IS, Rohanah, S, Muliyati, D 2020, 'The Development of Blended Learning Model using Edmodo to Train Student Critical Thinking Skills on Impulse-Momentum Topic', Jurnal Penelitian dan Pengembangan Pendidikan Fisika (JPPPF), vol. 6, no.1, pp. 113-20.

Departemen Pendidikan Nasional 2008, 'Pengembangan Bahan Ajar dan Media', Jakarta: Departemen Pendidikan Nasional.

Eveline, E, Suparno, Ardiyanti, TK, Dasilva, BE 2019, 'Development of Interactive Physics Mobile Learning Media for Enhancing Student's HOTS in Impulse and Momentum with Scaffolding Learning Approach', Jurnal Penelitian dan Pengembagan Pendidikan Fisika (JPPPF), vol. 5. no. 2, pp. 123-32.

Habibbulloh, M, Jatmiko \& Widodo, W 2017, 'Pengembangan Perangkat Pembekajaran Model Guided Discovery Berbasis Lab Virtual Untuk Mereduksi Miskonsepsi Siswa SMK Topik Efek Fotolistrik', Jurnal Penelitian FIsika Dan Aplikasinya (JPFA), vol. 07, no. 01, pp. 27-43.

Krouska, A, Troussas,C, \&Virvou M 2017, 'Comparing LMS and CMS Platforms Supporting Social e-Learning in Higher Education', Conference: 2017 8th International Conference on Information, Intelligence, Systems \& Applications (IISA), pp. 1-6.

Liu, TC 2007, 'Teaching in a Wireless Learning Environment: A Case Study', Educational Technology and Society, vol. 10, no. 1, pp. 107-23.

Malik, A, Vitriani \& Chusni, MM 2018, 'Improving Students' Critical-Thinking Skills Through Student Facilitator and Explaining Model in Momentum and Impuls Topic', Jurnal Penelitian dan Pengembangan Pendidikan Fisika (JPPPF), vol. 4, no. 2, pp. 55-64.

Martin, A \& Madigan, D 2006, 'Digital Literacies for Learning', London: Facet Publishing.

Putri, RF \& Jumadi, J 2017, 'Kemampuan guru fisika dalam menerapkan model-model pembelajaran pada kuriulum 2013 serta kendala-kendala yang dihadapi', Jurnal Inovasi Pendidikan IPA, vol. 3, no. 2, pp. 201-11.

Qomariyah, S, Gunarhadi \& Rejekiningsih, T 2018, 'Edmodo in Blended Learning to Increase Language Learners' Understanding in Learning Grammar for Toef', International Journal of Educational Research Review, vol. 4, no. 1, pp. 82-7.

Rahmi, Ulfia, Jasrial, J, Ansyar, M \& Effendi, ZM 2018, 'The Development of Message-Design Model in Blended Learning', The Asian Journal of Technology Management (AJTM). Vol. 10, no.1, pp. 19.

Rezeki, S \& Ishafit 2017, 'Pengembangan Media Pembelajaran Interaktif untuk Sekolah Menengah Atas Kelas XI pada Pokok Bahasan Momentum', Jurnal Penelitian dan Pengembangan Pendidikan Fisika (JPPPF), vol. 3, no.1, pp. 29-34.

Suprihatiningrum, J 2013, 'Strategi Pembelajaran Teori dan Aplikasi', AR-Ruzz Media. Yogyakarta.

Susilo, PH, Rohman, MG 2019, 'Sistem Pembelajaran Online Berbasis Aplikasi Web Menggunakan Framework Codeigniter', JOUTICA, vol. 4, no. 2, pp. 281-86.

Thiagarajan, S, Semmel, DS, and Semeel, MI 1974, 'Instructional Development for Training Teachers of Exceptional Children: A Sourcebook', Journal of School Psychology, vol. 14, no. 1, p. 75. 
Trinder, R 2015, 'Blending Technology and Face-to-Face: Advanced Students' Choices', ReCALL, vol. 28, no. 1, pp. 83-102.

Usman, S 2018, 'Sekolah Masa Depan Di Era Digital Belajar Dan Mengajar Di Mana Saja', The Conversation.

Widoyoko, S \& Eko, P 2011, 'Evaluasi program pembelajaran’, Yogyakarta: Pustaka Pelajar.

Wijayanti, W, Maharta N \& Suana W 2017, 'Pengembangan Perangkat Blended Learning Berbasis Learning Management System Pada Materi Listrik Dinamis', Jurnal Ilmiah Pendidikan Fisika AlBiruni, vol. 6, no. 1, p. 1 .

Yusnia, D \& Suparman 2018, 'Analisis Kebutuhan Bahan Ajar Berbasis Guided Discovery', Prosiding Seminar Nasional Etnomatnesia, pp. 395-99. 
